\title{
Erratum to: An empirical view on the determinants of sustainable economic development: Evidence from EU(28) member states
}

\author{
Beata Sofrankova*1, Dana Kiselakova $^{1}$, Erika Onuferova ${ }^{1}$, and Veronika Cabinova ${ }^{2}$ \\ ${ }^{1}$ University of Presov in Presov, Faculty of Management, Konstantinova 16, 08001 Presov, Slovak Republic \\ ${ }^{2}$ University of Presov in Presov, Ul. 17. Novembra 15, 08001 Presov, Slovak Republic \\ * Corresponding author: beata.sofrankova@unipo.sk
}

Original article:

SHS Web of Conferences

Volume 91 (2021)

Innovative Economic Symposium 2020 - Stable Development in Unstable World (IES2020)

https://doi.org/10.1051/shsconf/20219101008

This erratum corrects one mistake appearing in the original article.

1. One author and his affiliation is missing.

Beata Sofrankova ${ }^{1}$, Dana Kiselakova $^{1}$, Erika Onuferova ${ }^{1}$, and Veronika Cabinova ${ }^{2}$

${ }^{1}$ University of Presov in Presov, Faculty of Management, Konstantinova 16, 08001 Presov, Slovak Republic

${ }^{2}$ University of Presov in Presov, Ul. 17. Novembra 15, 08001 Presov, Slovak Republic 